\title{
Screening and Safety Evaluation of Herbicides in Oat Field
}

\author{
Weimin Song1,2, Liangzhi Guo ${ }^{1,2,3,4}$, Hua Weng ${ }^{1,2,3,4}$, Liang Cheng1,2,3,4, Youhai Wei ${ }^{1,2,3,4^{*}}$ \\ ${ }^{1}$ Qinghai University, Xining, China \\ ${ }^{2}$ College of Agriculture and Forestry Sciences, Qinghai University, Xining, China \\ ${ }^{3}$ Key Laboratory of Comprehensive Management of Agricultural Pests, Xining, China \\ ${ }^{4}$ Xining Crop Pest Scientific Observation and Experimental Station of the Ministry of Agriculture and Rural Affairs, Xining, China \\ Email: *youhaiweiqh@163.com
}

How to cite this paper: Song, W.M., Guo, L.Z., Weng, H., Cheng, L. and Wei, Y.H. (2021) Screening and Safety Evaluation of Herbicides in Oat Field. Open Access Library Journal, 8: e7462.

https://doi.org/10.4236/oalib.1107462

Received: April 27, 2021

Accepted: May 25, 2021

Published: May 28, 2021

Copyright $\odot 2021$ by author(s) and Open Access Library Inc.

This work is licensed under the Creative Commons Attribution International License (CC BY 4.0).

http://creativecommons.org/licenses/by/4.0/

\begin{abstract}
In order to screen safe and efficient herbicide varieties and combinations suitable for oat field use, field plot experiment method was used to spray stems and leaves from 3 to 5 leaf stages of oat. The results showed that the control effects of single-dose treatment of $45.9 \%$ difluoro-dioctyl SC $450 \mathrm{~mL} / \mathrm{hm}^{2}$ and $20 \%$ tribenuron-chlorofluoropyroxyacetic acid WP $900 \mathrm{~g} / \mathrm{hm}^{2}$ on weeds in oat fields were all above $80 \%$, herbicides $10 \%$ tribenuron-methyl WP $150 \mathrm{~g} / \mathrm{hm}^{2}$, $42 \%$ 2-methyl-fluroxypyr EC $1125 \mathrm{~mL} / \mathrm{hm}^{2}, 48 \%$ bentazone AS $3000 \mathrm{~mL} / \mathrm{hm}^{2}$ and 72\% 2,4-D butylate EC $150 \mathrm{~mL} / \mathrm{hm}^{2}$ mixed use, and 10\% pyrazone WP $300 \mathrm{~g} / \mathrm{hm}^{2}+56 \% 2$-methyl 4-sodium chloride WP $1200 \mathrm{~g} / \mathrm{hm}^{2}+50 \mathrm{~g} / \mathrm{L}$ difluorsulphonamide SC $90 \mathrm{~mL} / \mathrm{hm}^{2}$ mixed use of broad-leaved weeds in oat field control effect were more than $80 \%$, significantly higher than the conventional herbicide used in production, $48 \%$ bentazone AS $3000 \mathrm{~mL} / \mathrm{hm}^{2}+72 \%$ 2,4-D butylate EC $150 \mathrm{~mL} / \mathrm{hm}^{2}$ and 2-methyl-fluroxypyr EC $1125 \mathrm{~mL} / \mathrm{hm}^{2}+$ $72 \%$. The test results enriched the available herbicide varieties for chemical weeding in oat fields and could be applied in oat fields.
\end{abstract}

\section{Subject Areas}

Agricultural Science

\section{Keywords}

Oats, Herbicides, Mixed, Control Effect, Safety

\section{Introduction}

Oat (Avena sativa) is a one-year-old dual-purpose crop with the sixth largest planting area in the world. It has wide adaptability, high yield and health care 
function [1] [2]. Oat is the only forage crop that adapts to alpine pastoral areas [2]. Oat planting area in Qinghai accounts for more than 70\% of the artificial grass planting area in Qinghai Province [1], which plays a vital role in animal husbandry and social and economic development in alpine regions of Qinghai Province [3] [4] [5]. In production, the commonly used 2,4-D butylate EC and tribenuron-methyl herbicides are used to control weeds, and the problem of resistance to drug-resistant weeds such as Galium spurium L. and Lepyrodiclis holosteoides is becoming increasingly prominent. In order to pursue the control effect of weeds, the use of wheat herbicides also leads to the coexistence of efficacy and drug damage [6]. When the weed density in the field reaches above 50 plants $/ \mathrm{m}^{2}$, the wheat yield can be reduced by $25 \%-40 \%$ [7]. The use of chemical herbicides can greatly affect the growth and reproduction of weeds in the field, and the mixed use of herbicides has the characteristics of enhancing the control effect, expanding the weed control spectrum and reducing the dosage [8] [9] [10]. In recent years, although there are reports on the use of herbicides in oat fields, there are few reports on reducing the use of chemical herbicides, reducing pollution to the ecological environment and ensuring oat yield under special natural conditions in Qinghai alpine and arid areas. Therefore, this study aims to enrich the herbicide varieties that can be used for weed control in oat fields, develop weed solutions for oat fields, delay the succession rate of weed communities in oat fields, and reduce the damage of herbicides to crops through experimental screening and crop safety evaluation of herbicides in oat fields.

\section{Materials and Methods}

\subsection{Test Materials}

(1) 10\% Bensulfuron WP, Shandong Qiaochang Chemical Co., Ltd. (2) $72 \%$ 2,4-D butyl ester EC, Dalian Songliao Chemical Co., Ltd. (3) 20\% chlorofluoropyroxyacetic acid EC (Tao, China) Co., Ltd. (4) 56\% sodium 2-methyl-4-chloro WP, Shandong Qiaochang Modern Agriculture Co., Ltd. (5) 10\% azone WP, Suruibang Pharmaceutical Factory Co., Ltd. (6) 48\% AS, BASF Plant Protection (Jiangsu) Co., Ltd. (7) 20\% Bensulfuron-chlorofluoropyroxyacetic acid WP (Mianyang Lier Chemical Co., Ltd.). (8) 42\% 2-methyl-chlorofluoropyridine EC (Hansheng Biotechnology Co., Ltd., Qingdao, Shandong Province). (9) 45.9\% difluorooctyl ester SC, Dow Yinong (China) Co., Ltd. (10) 30\% aminochlor.dichloropyridine acid AS (Chongqing Shuangfeng Chemical Co., Ltd.).

The tested crops are: Oat, variety Liner.

\subsection{Test Design and Method}

The test set $20 \%$ tribenuron-methyl-fluroxyacetic acid WP $900 \mathrm{~g} / \mathrm{hm}^{2}, 42 \%$ 2-methyl-fluroxypyr EC $1125 \mathrm{~mL} / \mathrm{hm}^{2}, 45.9 \%$ difluorooctyl SC $450 \mathrm{~mL} / \mathrm{hm}^{2}, 48 \%$ bentazone AS $3000 \mathrm{~mL} / \mathrm{hm}^{2}, 10 \%$ oxazolidinone WP $360 \mathrm{~g} / \mathrm{hm}^{2}, 30 \%$ chloramphenic acid AS $450 \mathrm{~mL} / \mathrm{hm}^{2}$ alone, $30 \%$ chloramphenic acid AS $450 \mathrm{~mL} / \mathrm{hm}^{2}$, $10 \%$ tribenuron-methyl WP $150 \mathrm{~g} / \mathrm{hm}^{2}, 42 \%$ 2-methyl-fluroxypyr EC $1125 \mathrm{~mL} / \mathrm{hm}^{2}$, 
$48 \%$ bentazone AS $3000 \mathrm{~mL} / \mathrm{hm}^{2}, 10 \%$ oxazolidinone WP $360 \mathrm{~g} / \mathrm{hm}^{2}$ and $72 \%$ 2,4-D butyl EC $150 \mathrm{~mL} / \mathrm{hm}^{2}$ mixed use and 10\% azone WP $300 \mathrm{~g} / \mathrm{hm}^{2}+56 \%$ sodium 2-methyl 4-chloro WP $1200 \mathrm{~g} / \mathrm{hm}^{2}+50 \mathrm{~g} / \mathrm{L}$ difluorsulphonamide SC 90 $\mathrm{mL} / \mathrm{hm}^{2}$ mixed use of 13 treatments as screening agent treatment, The commonly used 10\% tribenuron-methyl WP $150 \mathrm{~g} / \mathrm{hm}^{2}, 72 \%$ 2,4-D butylate EC $750 \mathrm{~mL} / \mathrm{hm}^{2}$, and $20 \%$ fluroxypyr EC $750 \mathrm{~mL} / \mathrm{hm}^{2}$ were used as control agents, and the water control (CK) without spraying and weeding was set up. A total of 17 treatments were repeated for 3 times, and 51 plots were arranged in random groups with an area of $5 \mathrm{~m} \times 4 \mathrm{~m}=20 \mathrm{~m}^{2}$.

The test was applied on $29 \mathrm{May}$, sunny day, northwest wind direction, temperature $12.5^{\circ} \mathrm{C}$, maximum temperature $19.1^{\circ} \mathrm{C}$, minimum temperature $6.3^{\circ} \mathrm{C}$, relative humidity $58 \%$. Over $85 \%$ of oats have 3 leaves and 1 heart to 5 leaves. The dominant weeds in the field are 4 - 5 leaves of Brassica napus, 1 - 3 pairs of Elsholtzia densa, 2 - 4 pairs of Lepyrodiclis holosteoides, 1 - 3 rounds of Galium spurium, 2 - 8 pairs of Thlaspi arvense and $1-4$ pairs of Chenopodium album.

The HD400 back-loaded manual sprayer (conical nozzle) produced by Linong Company of Singapore was used to spray stems and leaves from three to five leaves of oats, and the water amount was calculated at $300 \mathrm{~L} / \mathrm{hm}^{2}$.

\subsection{General Situation of Test Site}

The experiment was conducted in Zhujiazhuang Village, Lushaer Town, Huangzhong County, Qinghai Province, with an elevation of $2850 \mathrm{~m}$ and an annual precipitation of $550 \mathrm{~mm}$. It belongs to rain-fed agricultural area. The weed species in the field are mainly self-grown rape, Elsholtzia dense flower, thin capsule grass, calamus, quinoa and so on. The occurrence density is large and the distribution is uniform. The soil in the test site was chestnut soil. The soil organic matter content was $22.15 \mathrm{~g} \cdot \mathrm{kg}^{-1}, \mathrm{pH} 8.23$, total nitrogen content was $3.51 \mathrm{~g} \cdot \mathrm{kg}^{-1}$, total phosphorus content was $1.95 \mathrm{~g} \cdot \mathrm{kg}^{-1}$, total potassium content was 31.99 $\mathrm{g} \cdot \mathrm{kg}^{-1}$ and the terrain was flat.

The previous crop was rape (Qingyou 305).

\subsection{Experimental Investigation and Data Statistics}

\subsubsection{Investigation on Weed Control Efficacy}

The responses of weeds and crops to pesticides were observed at $7 \mathrm{~d}$ and $15 \mathrm{~d}$ after treatment. Three points were randomly sampled in each plot 30 days after application, with an area of $0.25 \mathrm{~m}^{2}$. The number of residual weeds in the treatment area was investigated, and the aboveground fresh weight was weighed to calculate the plant control effect and fresh weight control effect.

The efficacy calculation formula is:

Plant control $\%=[$ (number of plants in control area-number of plants in application area)/number of plants in control area $\times 100$

Fresh weight control effect $\%=[$ (control area fresh weight-application area fresh weight)/control area fresh weight $] \times 100$ 


\subsubsection{Crop Safety Assessment}

After treatment, the reaction of oats to each pesticide treatment was observed, and the leaf color growth of oats in the control area was compared with that in the blank area. After maturity, 3 points of diagonal sampling were taken in each plot, and the sample area was $1 \mathrm{~m}^{2}$.

Yield increase rate $\%=[($ treatment area yield-control area yield $) /$ control area yield] $\times 100$

\subsubsection{Data Processing}

Excel 2007 was used for data processing, and Duncan's new complex range method was used to determine the difference of control effect between the treatments.

\section{Results and Analysis}

\subsection{Effect of Different Experimental Treatments on Weed Control in Field}

Seven days after application, the growth and chlorosis of Blassikakapestris, Elsholtzia densa and Galium spurium in the tribenuron-methyl treatment area were inhibited, while the growth and chlorosis of Galium spurium, Lepyrodiclis holosteoides and Blassikakapestris. In the tribenuron-methyl treatment area were significantly inhibited. In $30 \%$ AS treatment, the growth of rapeseed was normal, while Elsholtzia densa, Lepyrodiclis holosteoides and Galium spurium were inhibited. After 15 days, Elsholtzia densa, Lepyrodiclis holosteoides, Galium spurium and other weeds in $30 \%$ AS and $30 \%$ AS + $72 \%$ 2,4-D butyl ester EC treatments recovered to varying degrees. The weed damage in other treatment areas was aggravated, and dead plants were observed in some treatment areas. The experimental investigation was carried out 30 days after the application, and the control effect of each treatment area on weeds was counted. The results are shown in Table 1. The control effect of $45.9 \%$ difluorooctyl SC $450 \mathrm{~mL} / \mathrm{hm}^{2}$ on weeds was $93.90 \%$, and the control effect of fresh weight was $82.30 \%$. The control effect of $20 \%$ bensulfuron-methyl-chlorofluoropyroxyacetic acid WP 900 $\mathrm{g} / \mathrm{hm}^{2}$ on weeds was $87.59 \%$, and the control effect of fresh weight was $86.56 \%$. The control effect of $10 \%$ bensulfuron-methyl WP $150 \mathrm{~g} / \mathrm{hm}^{2}+72 \%$ 2,4-D butyl EC $150 \mathrm{~mL} / \mathrm{hm}^{2}$ on weeds was $89.00 \%$, and the control effect of fresh weight was $89.83 \%$. The control effect of $42 \%$ methyl-chlorofluoropyroxyacetic acid EC 1125 $\mathrm{mL} / \mathrm{hm}^{2}+72 \%$ 2,4-D butyl EC $150 \mathrm{~mL} / \mathrm{hm}^{2}$ on weeds was $97.3 \%$, and the control effect of fresh weight was $93.99 \%$, The control effect of $10 \%$ acetochlor WP $300 \mathrm{~g} / \mathrm{hm}^{2}+56 \%$ sodium 2-methyl 4-chloro WP $1200 \mathrm{~g} / \mathrm{hm}^{2}+50 \mathrm{~g} / \mathrm{L}$ difluorfen SC $90 \mathrm{~mL} / \mathrm{hm}^{2}$ on weeds was $89.90 \%$, and the control effect of fresh weight was $88.58 \%$, which was better than that of $10 \%$ tribenuron-methyl WP $150 \mathrm{~g} / \mathrm{hm}^{2}$, $72 \%$ 2,4-D butyl EC $750 \mathrm{~mL} / \mathrm{hm}^{2}$ and 20\% fluroxypyr EC $750 \mathrm{~mL} / \mathrm{hm}^{2}$ (about 75\%). 10\% acetochlor WP $360 \mathrm{~g} / \mathrm{hm}^{2}, 48 \%$ bentazone AS $3000 \mathrm{~mL} / \mathrm{hm}^{2}, 30 \%$ aminochlor-dichloropy-ridinic acid AS $450 \mathrm{~mL} / \mathrm{hm}^{2}$ and 72\% 2,4-D butyl ester EC $150 \mathrm{~mL} / \mathrm{hm}^{2}$ mixed treatment of weed control effect and fresh weight control 
Table 1. Control effect of different herbicide weeds in oat field.

\begin{tabular}{|c|c|c|c|c|c|}
\hline \multirow{2}{*}{ Experimental treatment } & \multirow{2}{*}{$\begin{array}{c}\text { Dosage } \\
\mathrm{g} \cdot \mathrm{mL} / \mathrm{hm}^{2}\end{array}$} & \multirow{2}{*}{$\begin{array}{c}\text { Plant defence } \\
\%\end{array}$} & \multirow{2}{*}{$\begin{array}{c}\text { Fresh weight } \\
\text { control effect } \\
\\
\%\end{array}$} & \multicolumn{2}{|c|}{ Oat yield } \\
\hline & & & & $\mathrm{kg} / \mathrm{hm}^{2}$ & $\begin{array}{l}\text { Yield increasing } \\
\quad \text { rate } \pm \%\end{array}$ \\
\hline Blank (sytrain, $\mathrm{g} / \mathrm{m}^{2}$ ) & 0 & $426.03 \mathrm{a} \mathrm{A}$ & $615.81 \mathrm{a} \mathrm{A}$ & $4125.37 \mathrm{o} O$ & 0 \\
\hline 45.9\% Difluorooctyl SC & 450 & 93.9de B & $82.3 \mathrm{bcd} \mathrm{C}$ & $4569.27 \mathrm{e} E$ & 10.76 \\
\hline 20\% Bensulfuron·chlorofluoropyroxyacetic acid WP & 900 & 87.59 cde B & $86.56 \mathrm{bcd} \mathrm{C}$ & $4562.86 \mathrm{f} \mathrm{F}$ & 10.60 \\
\hline $10 \%$ Bensulfuron WP + 72\% 2,4-D Butyl EC & $150+150$ & $89.00 \mathrm{cde} \mathrm{B}$ & $89.83 \mathrm{bcd} \mathrm{C}$ & 4587.66d D & 11.21 \\
\hline $\begin{array}{l}42 \% 2 \text { methyl-chlorofluoropyridine EC + 72\% 2,4-D } \\
\text { butyl EC }\end{array}$ & $1125+150$ & $97.30 \mathrm{e} B$ & $93.99 \mathrm{~cd} \mathrm{C}$ & 4695.31a A & 13.82 \\
\hline $48 \%$ Patrol AS + 72\% 2,4-D butyl ester EC & $3000+150$ & $93.08 \mathrm{e} B$ & $94.64 \mathrm{~d} \mathrm{C}$ & $4643.93 b$ B & 12.57 \\
\hline $\begin{array}{l}10 \% \text { azone } \mathrm{WP}+56 \% \text { sodium } 2 \text {-methyl- } 4 \text {-chloro } \\
\mathrm{WP}+50 \mathrm{~g} / \mathrm{L} \text { sulfenachlor SC }\end{array}$ & $300+1200+90$ & $89.90 \mathrm{cde} \mathrm{B}$ & $88.58 \mathrm{bcd} \mathrm{C}$ & 4590.63 c C & 11.28 \\
\hline $42 \%$ 2-methyl-chlorofluoropyridine EC & 1125 & $85.22 \mathrm{cde} \mathrm{B}$ & $76.85 \mathrm{bcd} \mathrm{C}$ & $4452.52 \mathrm{~g} \mathrm{G}$ & 7.93 \\
\hline $48 \%$ Patrol AS & 3000 & $19.94 \mathrm{ab} \mathrm{A}$ & 61.56a ABC & $4241.74 \mathrm{~m} \mathrm{M}$ & 2.82 \\
\hline 10\% Azone WP & 360 & 69.96bcde $\mathrm{AB}$ & $72.54 \mathrm{~b} \mathrm{ABC}$ & $4372.12 \mathrm{k} \mathrm{K}$ & 5.98 \\
\hline $10 \%$ Azone WP + 72\% 2,4-D Butyl EC & $360+150$ & $75.59 \mathrm{bcde} A B$ & $75.48 \mathrm{bcd} \mathrm{BC}$ & $4421.87 \mathrm{j} \mathrm{J}$ & 7.19 \\
\hline $30 \%$ Aminochlor dichloropyridine acid AS & 450 & $53.76 \mathrm{abcd} A B$ & $65.31 \mathrm{~b} \mathrm{ABC}$ & $4348.231 \mathrm{~L}$ & 5.40 \\
\hline $\begin{array}{l}30 \% \text { Aminochlor-dichloropyridine acid AS +72\% 2,4-D } \\
\text { Butyl EC }\end{array}$ & $450+150$ & $48.35 \mathrm{abc} \mathrm{AB}$ & $12.15 \mathrm{a} \mathrm{A}$ & $4210.04 \mathrm{n} \mathrm{N}$ & 2.05 \\
\hline $10 \%$ Bensulfuron WP & 150 & 83.57cde AB & $69.87 \mathrm{bc} B C$ & $4373.64 \mathrm{k} \mathrm{K}$ & 6.02 \\
\hline 72\% 2,4-D Butyl EC & 750 & 78.41cde AB & $78.57 \mathrm{bcd} \mathrm{C}$ & $4432.19 \mathrm{~h} \mathrm{H}$ & 7.44 \\
\hline 20\% Chlorofluoropyroxyacetic acid EC & 750 & 73.25bcde AB & $72.72 \mathrm{bcd} B C$ & $4428.94 \mathrm{i} \mathrm{I}$ & 7.36 \\
\hline
\end{tabular}

Note: After the same data in the table, different capital letters and capital letters showed significant difference $(P<0.01)$ and significant difference $(P<0.05)$.

effect is about $70 \%$ or lower.

The control effects of different herbicide varieties or herbicide combinations on dominant weeds in oat fields were statistically analyzed (Table 2 and Table 3 ). The results showed that the control effects of single treatment of $45.9 \%$ difluorooctyl SC $450 \mathrm{~mL} / \mathrm{hm}^{2}$ and $20 \%$ tribenuron-chlorofluoropyroxyacetic acid WP $900 \mathrm{~g} / \mathrm{hm}^{2}$ on dominant weeds in oat fields were all above $80 \%$. The control effects of $10 \%$ tribenuron WP $150 \mathrm{~g} / \mathrm{hm}^{2}, 42 \%$ dimethyl.chlorofluoropyr EC $1125 \mathrm{~mL} / \mathrm{hm}^{2}, 48 \%$ papyran AS $3000 \mathrm{~mL} / \mathrm{hm}^{2}$ and 72\% 2,4-D butyl EC 150 $\mathrm{mL} / \mathrm{hm}^{2}$, and $10 \%$ azone WP $300 \mathrm{~g} / \mathrm{hm}^{2}+56 \%$ methyl 4 sodium chloride WP $1200 \mathrm{~g} / \mathrm{hm}^{2}+50 \mathrm{~g} / \mathrm{L}$ difluorosulfonamide SC $90 \mathrm{~mL} / \mathrm{hm}^{2}$ and $72 \%$ tribenuron-ethyl EC $750 \mathrm{~mL} / \mathrm{hm}^{2}$ on dominant weeds in oat fields. $30 \%$ Chloramphenic acid AS is mainly used for weed control in rape field. 
Table 2. Effects of different herbicides on dominant weeds in oat field.

\begin{tabular}{|c|c|c|c|c|c|}
\hline \multirow[b]{2}{*}{ Experimental treatment } & \multirow{2}{*}{$\begin{array}{c}\text { Dosage } \\
\mathrm{g} \cdot \mathrm{mL} / \mathrm{hm}^{2}\end{array}$} & \multicolumn{4}{|c|}{ Plant defence \% } \\
\hline & & Blassikakapestris & $\begin{array}{c}\text { Elsholtzia } \\
\text { densa }\end{array}$ & $\begin{array}{l}\text { Galium } \\
\text { spurium }\end{array}$ & $\begin{array}{l}\text { Lepyrodiclis } \\
\text { holosteoides }\end{array}$ \\
\hline Blank (sytrain, $\mathrm{g} / \mathrm{m}^{2}$ ) & 0 & 20.67 & 14.22 & 23.89 & 22.78 \\
\hline 45.9\% Difluorooctyl SC & 450 & 96.71 & 87.38 & 93.31 & 87.54 \\
\hline $20 \%$ Bensulfuron·chlorofluoropyroxyacetic acid WP & 900 & 94.63 & 85.94 & 91.26 & 92.28 \\
\hline $10 \%$ Bensulfuron WP + 72\% 2,4-D Butyl EC & $150+150$ & 92.25 & 90.39 & 94.68 & 92.53 \\
\hline $42 \% 2$ methyl-chlorofluoropyridine EC $+72 \%$ 2,4-D butyl EC & $1125+150$ & 96.03 & 94.23 & 97.81 & 96.41 \\
\hline $48 \%$ Patrol AS + 72\% 2,4-D butyl ester EC & $3000+150$ & 97.63 & 95.62 & 91.73 & 97.56 \\
\hline $\begin{array}{l}10 \% \text { azone WP + } 56 \% \text { sodium } 2 \text {-methyl-4-chloro WP + } 50 \mathrm{~g} / \mathrm{L} \\
\text { sulfenachlor SC }\end{array}$ & $300+1200+90$ & 98.52 & 91.40 & 94.53 & 96.73 \\
\hline $42 \%$ 2-methyl-chlorofluoropyridine EC & 1125 & 93.55 & 85.36 & 89.57 & 90.67 \\
\hline 48\% Patrol AS & 3000 & 90.32 & 78.82 & 68.59 & 96.11 \\
\hline $10 \%$ Azone WP & 360 & 86.02 & 68.75 & 65.72 & 67.99 \\
\hline $10 \%$ Azone WP + 72\% 2,4-D Butyl EC & $360+150$ & 89.79 & 78.13 & 74.29 & 72.06 \\
\hline 30\% Aminochlor-dichloropyridine acid AS & 450 & 0 & 41.27 & 54.33 & 53.03 \\
\hline $30 \%$ Aminochlor-dichloropyridine acid AS +72\% 2,4-D Butyl EC & $450+150$ & 80.65 & 71.87 & 31.45 & 28.06 \\
\hline $10 \%$ Bensulfuron WP & 150 & 89.10 & 69.53 & 68.55 & 72.06 \\
\hline $72 \%$ 2,4-D Butyl EC & 750 & 92.01 & 68.75 & 62.81 & 68.11 \\
\hline $20 \%$ Chlorofluoropyroxyacetic acid EC & 750 & 91.38 & 78.90 & 93.07 & 91.83 \\
\hline
\end{tabular}

Table 3. Effects of different herbicides on fresh weight of dominant weeds in oat field.

\begin{tabular}{|c|c|c|c|c|c|}
\hline \multirow[b]{2}{*}{ Experimental treatment } & \multirow{2}{*}{$\begin{array}{c}\text { Dosage } \\
\mathrm{g} \cdot \mathrm{mL} / \mathrm{hm}^{2}\end{array}$} & \multicolumn{4}{|c|}{ Fresh weight control effect \% } \\
\hline & & Blassikakapestris & $\begin{array}{l}\text { Elsholtzia } \\
\text { densa }\end{array}$ & $\begin{array}{l}\text { Galium } \\
\text { spurium }\end{array}$ & $\begin{array}{l}\text { Lepyrodiclis } \\
\text { holosteoides }\end{array}$ \\
\hline Blank (sytrain, g/m²) & 0 & 20.39 & 20.45 & 18.85 & 19.52 \\
\hline 45.9\% Difluorooctyl SC & 450 & 97.27 & 82.16 & 87.63 & 85.37 \\
\hline $20 \%$ Bensulfuron·chlorofluoropyroxyacetic acid WP & 900 & 92.56 & 83.72 & 89.34 & 84.88 \\
\hline $10 \%$ Bensulfuron WP $+72 \%$ 2,4-D Butyl EC & $150+150$ & 95.18 & 91.94 & 92.27 & 94.55 \\
\hline $42 \% 2$ methyl $\cdot$ chlorofluoropyridine EC $+72 \%$ 2,4-D butyl EC & $1125+150$ & 98.38 & 95.11 & 96.71 & 97.65 \\
\hline $48 \%$ Patrol AS + 72\% 2,4-D butyl ester EC & $3000+150$ & 98.62 & 96.52 & 94.33 & 95.31 \\
\hline $\begin{array}{l}10 \% \text { azone WP }+56 \% \text { sodium } 2 \text {-methyl-4-chloro WP }+50 \mathrm{~g} / \mathrm{L} \\
\text { sulfenachlor SC }\end{array}$ & $300+1200+90$ & 98.47 & 92.13 & 92.87 & 96.84 \\
\hline $48 \%$ Patrol AS & 3000 & 60.77 & 62.54 & 69.51 & 83.94 \\
\hline $10 \%$ Azone WP & 360 & 80.38 & 75.55 & 73.45 & 77.82 \\
\hline $10 \%$ Azone WP + 72\% 2,4-D Butyl EC & $360+150$ & 88.56 & 70.66 & 73.63 & 77.82 \\
\hline 30\% Aminochlor $\cdot$ dichloropyridine acid AS & 450 & 20.67 & 58.37 & 33.26 & 53.89 \\
\hline 30\% Aminochlor $\cdot$ dichloropyridine acid AS +72\% 2,4-D Butyl EC & $450+150$ & 15.01 & 20.15 & 13.52 & 16.34 \\
\hline $10 \%$ Bensulfuron WP & 150 & 81.22 & 74.47 & 69.12 & 67.57 \\
\hline $72 \%$ 2,4-D Butyl EC & 750 & 84.61 & 72.27 & $75 . .33$ & 74.39 \\
\hline 20\% Chlorofluoropyroxyacetic acid EC & 750 & 86.43 & 73.94 & 92.19 & 88.12 \\
\hline
\end{tabular}




\subsection{Safety Evaluation of Oats under Different Experimental Treatments}

After spraying, the leaves of oats in the treatment area were chlorotic and yellowed at $7 \mathrm{~d}$, and disappeared at $15 \mathrm{~d}$. There was no significant difference in leaf color between the other treatments and the blank control, and the growth of oat was normal in the middle and late growth stages. After maturity, the yield was measured. The results are shown in Table 1. The yield of clean water control area was $4125.37 \mathrm{~kg} / \mathrm{hm}^{2}, 10 \%$ tribenuron WP $150 \mathrm{~g} / \mathrm{hm}^{2}, 72 \%$ 2,4-D butyl EC $750 \mathrm{~mL} / \mathrm{hm}^{2}, 20 \%$ fluroxypyr EC $750 \mathrm{~mL} / \mathrm{hm}^{2}, 20 \%$ tribenuron-fluroxypyr WP $900 \mathrm{~g} / \mathrm{hm}^{2}, 42 \%$ dimethyl-fluroxypyr EC $1125 \mathrm{~mL} / \mathrm{hm}^{2}, 45.9 \%$ difluorooctyl ester SC $450 \mathrm{~mL} / \mathrm{hm}^{2}$, 10\% oxadiazolone WP $360 \mathrm{~g} / \mathrm{hm}^{2}, 30 \%$ ammonia chloride.dichloropyridine acid AS $450 \mathrm{~mL} / \mathrm{hm}^{2}$, which were all above $5 \%$ higher than those of the blank control, and the yield of $48 \%$ bentazone AS $3000 \mathrm{~mL} / \mathrm{hm}^{2}$ was $2.82 \%$. The mixed herbicide 10\% tribenuron-methyl WP $150 \mathrm{~g} / \mathrm{hm}^{2}+72 \%$ 2,4-D butyl EC $150 \mathrm{~mL} / \mathrm{hm}^{2}, 42 \%$ 2-methyl-fluroxypyr EC $1125 \mathrm{~mL} / \mathrm{hm}^{2}+72 \%$ 2,4-D butyl EC $150 \mathrm{~mL} / \mathrm{hm}^{2}, 48 \%$ bentazone AS $3000 \mathrm{~mL} / \mathrm{hm}^{2}+72 \%$ 2,4-D butyl EC 150 $\mathrm{mL} / \mathrm{hm}^{2}, 10 \%$ azone WP $300 \mathrm{~g} / \mathrm{hm}^{2}+56 \%$ 2-methyl sodium chloride WP 1200 $\mathrm{g} / \mathrm{hm}^{2}+50 \mathrm{~g} / \mathrm{L}$ difluorosulphonamide SC $90 \mathrm{~mL} / \mathrm{hm}^{2}$ increased yield more than $11 \%$ compared with the blank control, 30\% aminochlor-dichloropyridine acid AS $450 \mathrm{~mL} / \mathrm{hm}^{2}+72 \%$ 2,4-D butyl EC $150 \mathrm{~mL} / \mathrm{hm}^{2}$ and 10\% azone WP 360 $\mathrm{g} / \mathrm{hm}^{2}+72 \%$ 2,4-D butyl EC $150 \mathrm{~mL} / \mathrm{hm}^{2}$ increased yield by $2.05 \%$ and $7.19 \%$, respectively.

\section{Summary}

The results of this experiment showed that the control effects of herbicides $45.9 \%$ difluorooctyl SC $450 \mathrm{~mL} / \mathrm{hm}^{2}$ and $20 \%$

bensulfuron-methyl.chlorofluoropyroxyacetic acid WP $900 \mathrm{~g} / \mathrm{hm}^{2}$ on broadleaf weeds in oat fields were all above $80 \%$, and the control effects of $10 \%$ bensulfuron-methyl WP $150 \mathrm{~g} / \mathrm{hm}^{2}, 42 \%$ dimethyl-chlorofluoropyroxyacetic acid WP 1125 $\mathrm{mL} / \mathrm{hm}^{2}, 48 \%$ Patrol AS $3000 \mathrm{~mL} / \mathrm{hm}^{2}$ and 72\% 2,4-D butyl EC $150 \mathrm{~mL} / \mathrm{hm}^{2}$ on broadleaf weeds in oat fields were all significantly higher than those of conventional herbicides $85 \%$ on broadleaf weeds in oat fields, and the control effects of $10 \%$ azone WP $300 \mathrm{~g} / \mathrm{hm}^{2}+56 \%$ methyl 4 sodium chloride WP $1200 \mathrm{~g} / \mathrm{hm}^{2}+50$ g/L bensulfuron-methyl SC $90 \mathrm{~mL} / \mathrm{hm}^{2}$, Among them, 48\% Paicaodan AS 3000 $\mathrm{mL} / \mathrm{hm}^{2}+72 \%$ 2,4-D butyl EC $150 \mathrm{~mL} / \mathrm{hm}^{2}$ and 2 methyl.chlorofluoropyr EC $1125 \mathrm{~mL} / \mathrm{hm}^{2}+72 \%$ 2,4-D butyl EC $150 \mathrm{~mL} / \mathrm{hm}^{2}$ were sprayed on the stems and leaves of oats from 3-leaf stage to 5-leaf stage, and the overall control effect on weeds was more than $90 \%$. It had good control effect on the dominant weeds such as Blassikakapestris, Elsholtzia densa, Galium spurium and Chenopodium album in oat field. It was safe for the tested oat varieties Liner, and the yield increased significantly after weeding.. Due to the long-term and single use of herbicides, the selective pressure of herbicides is increased, which further leads to the resistance of weeds to herbicides. Therefore, it is suggested that the above 
herbicide varieties or mixed combinations should be used alternately in oat fields to prevent the resistance of weeds and delay the succession rate of weed communities.

\section{Conflicts of Interest}

The authors declare no conflicts of interest regarding the publication of this paper.

\section{References}

[1] Zhao, G.Q., and Shi, S.L. (2004) The Current Situation of Oat Research and Production, Problems and Strategy in Tibetan Plateau. Pratacultural Science, 21, 17-21.

[2] Xu, C.L. (2012) A Study on Growth Characteristics of Different Cultivars of Oat (Avena sativa) in Alpine Region. Acta Prataculturae Sinica, 21, 280-285.

[3] Wang, Y., Gao Z.H., Bai, M.E., He, Y.F. and Gao, L.D. (2001) Recent Developments in Chemical Weed Killer and Its Application in Forestry in China. Journal of Zhejiang Forestry Science and Technology, 6, 61-64.

[4] Xiao, X.J., Zhou, Q.P., Chen, Y.J., Du, Z., Bai, X.L. and Tian, L.H. et al. (2017) Effect of Seeding Rate on Production Performance and Photosynthetic Characteristics of Avena Sativa cv. LENA in Alpine Pastoral Region. Pratacultural Science, 34, 761-771.

[5] Wu, X.M., Du, J.H., Zeng, Y. and Diao, Z.M. (2002) Analysis on the Resources of the Oat varieties in Qinghai Province. Acta Botanica Boreali-Occidentalia Sinica, 1, 158-162.

[6] Wei, Y.H. (2012) Control Effect and Safety Evaluation of 20\% Chlorpyrifos Tribenuron Methyl WP on Weeds in Spring Wheat Field. Jiangsu Agricultural Sciences, 40, 140-141.

[7] Gou, Z.Q., Liu, H., Zhao, G.Q., Chai, J.K., Xu, X.Z. and Zeng, L. (2018) Weed Control Effect of Two Herbicides Mixture in Oat Field. Grassland and Turf, 38, 73-78.

[8] Gou, Z.Q. (2018) Study on Weed Control Effect of Herbicides Mixture Oats Field. Ph.D. Thesis, Gansu Agricultural University, Gansu.

[9] Hu, Z.C., Zhao, G.Q., Liu, H., Liu, Y.G. and Xu, W.C. (2012) Effects of Herbicides on Weed Control and Grain Yield of Oat. Journal of Gansu Agricultural University, 47, 97-103.

[10] Wang, Y.S., Zhang, W., Jia, J., Meng, L.M., Su, Q.F. and Chang, X. (2021) Evaluation of Proportioning Screen and Application of the Combination of Flufenacet and Prometryne. Agrochemicals, 60, 226-229. 